\title{
ОТРИМАННЯ ТРАНСГЕННИХ РОСЛИН ТЮТЮНУ ТА МАНГОЛЬДУ, ЩО ЕКСПРЕСУЮТЬ РЕКОМБННАНТНИЙ ГЕН ІНТЕРФЕРОНУ ЛЮДИНИ АЛЬФА
}

\author{
К.О. Ситник ${ }^{\mathbf{1}}$ Ю.С. Лучаківська ${ }^{1,2}$ \\ ${ }^{1}$ Київський Палаи дітей та юнацтва \\ вул. Івана Мазепи, 13, м. Київ, 01010, Україна \\ ${ }^{2}$ Інститут клітинної біології та генетичної інженерії НАН України \\ вул. Академіка Заболотного, 148, м. Київ, 03143, Україна \\ e-mail: katiasytnyk@gmail.com
}

Інтерферон альфа - лейкоцитарний секреторний білок неспецифічного імунітету людини. Інтерферон альфа 2b використовують в медицині для лікування раку печінки [1], сечового міхура [2], гепатитів C [3], B, COVID-19 [4], хронічного мієлоїдного лейкозу [5], меланоми [6], також цей білок є критично важливим для контролю ВІЛ [7].

Сьогодні в промислових масштабах рекомбінантний інтерферон отримують в культурах бактеріальних (Escherichia coli) і тваринних (Hamster Ovary Cells) клітин. Синтез білка в рослинних клітинах вважається безпечнішим, оскільки дозволяє уникнути додаткової очистки препарату (від можливої контамінації бактеріальними токсинами або тваринними вірусами і пріонами), та дешевшим, адже білок не потребуватиме посттрансляційних модифікацій, що $є$ необхідними при використанні бактеріальних експресійних систем, чи вартісних умов культивування у випадку використання культур тваринних клітин. Крім того, накопичення рекомбінантних білків в рослинах уможливлює їх транспортування без холодильників і значно спрощує їх зберігання. До того, використання трансгенних рослин, що можуть вживатися в їжу у сирому вигляді, дозволяє уникнути необхідності вартісного очищення білкового продукту та необхідності використання спеціального медичного обладнання. Але, в той же час, актуальною залишається можливість паралельної препаративної очистки цільового білка 3 метою подальшого вивчення його біологічних властивостей. Таким чином, в нашій роботі ми плануємо використання рекомбінантного гену інтерферону альфа людини злитого з his-tag послідовністю, що уможливило б його афінну очистку з рослинних тканин.

Отже, метою представленої роботи є отримання трансгенних рослин тютюну та мангольду, що містять ген рекомбінантного інтерферону альфа $2 \mathrm{~b}$ злитого 3 his-tag послідовністю.

Для генетичної трансформації мангольду (Beta vulgaris L.) використовували асептичні проростки рослин сортів Ізумруд, Алий, Міраж. Гіпокотильні експланти та сім'ядольне листя мангольду культивували на живильному середовищі MS з додаванням 2 мг/л БАП протягом двох тижнів перед інокульованням агробактеріальною суспензією. Модельні рослини тютюну Nicotiana tabacum L. сорту Вірджинія також вирощували на середовищі MS при кімнатній температурі $\left(20-22^{\circ} \mathrm{C}\right)$. 


\section{pNPB0030}

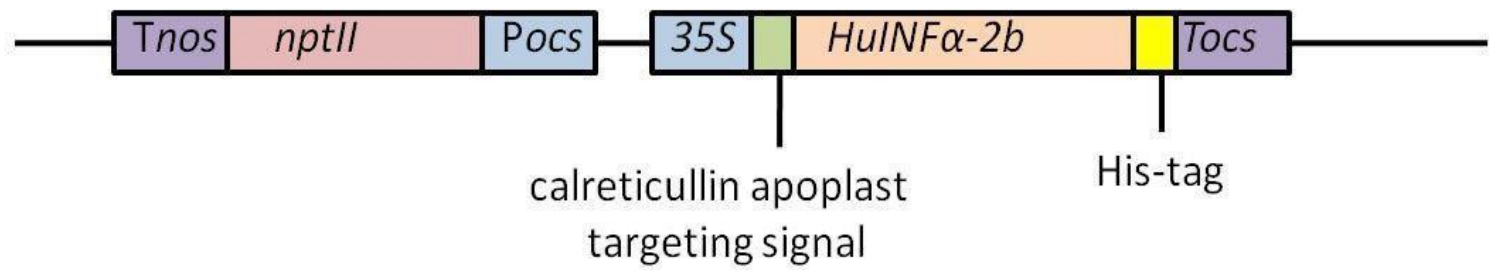

Рисунок 1. Векторна конструкція рNPB0030

LB, RB - праві та ліві межі T-ДНК, HиINF $\alpha-2 b$ - ген інтерферону альфа-2b людини; прtII - ген неоміцинфосфотрансферази; calreticullin targeting signal - лідерна послідовність рослинного кальретикулінового сигналу таргетингу цілььового білку в апопласт; $35 \mathrm{~S}$ - 35S промотор вірусу мозаїки ивітної капусти;Pnos, Tnos - промотор та термінатор гену нопалінсинтетази; Тосs - термінатор гену октопінсинтетази.

Векторну конструкцію рNPB0030 (рис.1), що містила цільовий ген інтерферону альфа, злитий з апопластним сигналом таргетингу і his-tag послідовністю, та селективний ген $n p t I I$, що обумовлював стійкість рослинних клітин до антибіотику канаміцину, було люб'язно надано Інститутом клітинної біології та генетичної інженерії НАН України. Для отримання суспензійної бактеріальної культури Agrobacterium tumefaciens (штам GV 3101), що містила плазмідний вектор pNPB0030, використовували рідке середовище LB, що містило 50 мг/л карбеніциліну та 25 мг/л рифампіцину, та культивували на орбітальному шейкері при постійному перемішуванні (200 об./хв.) за температури $28^{\circ} \mathrm{C}$.

Для трансформації рослин тютюну бактеріальну культуру осаджували за допомогою центрифугування та надалі ресуспендували в рідкому живильному середовищі MS. Трансформації піддавали листкові експланти модельної рослини шляхом нанесення дрібних ушкоджень за допомогою скальпеля і подальшого перенесення їх у рідке середовище 3 культурою агробактерій. Через 2 доби трансформовані експланти переносили на середовище MS із додаванням 0,1 мг/л нафтилоцтової кислоти (НОК) і 1 мг/л 6-бензинаминопурину (БАП) для ініціації регенерації рослин, 500 мг/л антибіотику цефотаксиму для елімінації бактерії і 100 мг/л селективного антибіотику канаміцину, в умовах кімнатної температури і постійного освітлення.

Для трансформації рослин мангольду суспензійну бактеріальну культуру осаджували центрифугуванням (5000 об./хв., $\left.4^{\circ} \mathrm{C}\right)$. Отриманий осад ресуспендували у рідкому MS середовищі, що додатково містило 200 мкМ ацетосирингону, та надалі культивували на ротаційному шейкері за температури $28^{\circ} \mathrm{C}$ та 200 об./хв. протягом години. Гіпокотильні та сім'ядольні експланти асептичних проростків мангольди після інкубування протягом 5-10 хв. 
у отриманій бактеріальній суспензійній культурі, піддавали вакуум-інфільтрації. Генетична трансформація проходила на стерильному фільтрувальному папері протягом 48 годин на розсіяному світлі. В подальшому експланти переносили на агаризоване живильне середовище MS с додаванням 100 мг/л антибіотику канаміцинсульфату в якості селективного агенту, 500 мг/л антибіотику цефотаксиму для елімінації бактерій та 1 мг/л БАП, 0,3 мг/л НОК, 0,4 мг/л ГК, тіосульфату срібла, 0,5 г/л ПВП, 0,1 г/л проліну для ініціації регенерації рослин мангольду та культивували за температури $24^{\circ} \mathrm{C}, 16$-годинному фотоперіоді.

Сумарну рослинну ДНК екстрагували згідно Doyle J.L. та Doyle J.J.[8] Присутність трансгенів підтверджували за допомогою аналізу методом ПЛР. Ампліфікацію фрагменту цільового гену людського інтерферону альфа $H u I N F \alpha-2 b$ (264 п.н.) проводили 3 використанням праймерів 5'-ctcctgcttgaaggacag-3', 5'-ggagtcctccttcatcag-3' проводили одночасно $з$ ампліфікацією фрагменту гену агробактерії (virDl - 432 п.н.) з використанням праймерів 5'-atgtcgcaaggcagtaagccca-3', 5'-ggagtctttcagcatggagcaa-3'; для ампліфікації фрагмента селективного гена nptII (622 п.н.) ПЛР проводили 3 використанням праймерів 5'cctgaatgaactccaggacgaggcaa-3', 5'-gctctagatccagaggtcccgctcagaag-3'. Продукти реакції фракціонували в $1 \%$ агарозному гелі у присутності бромистого етидію в трис-ацетатній буферній системі.
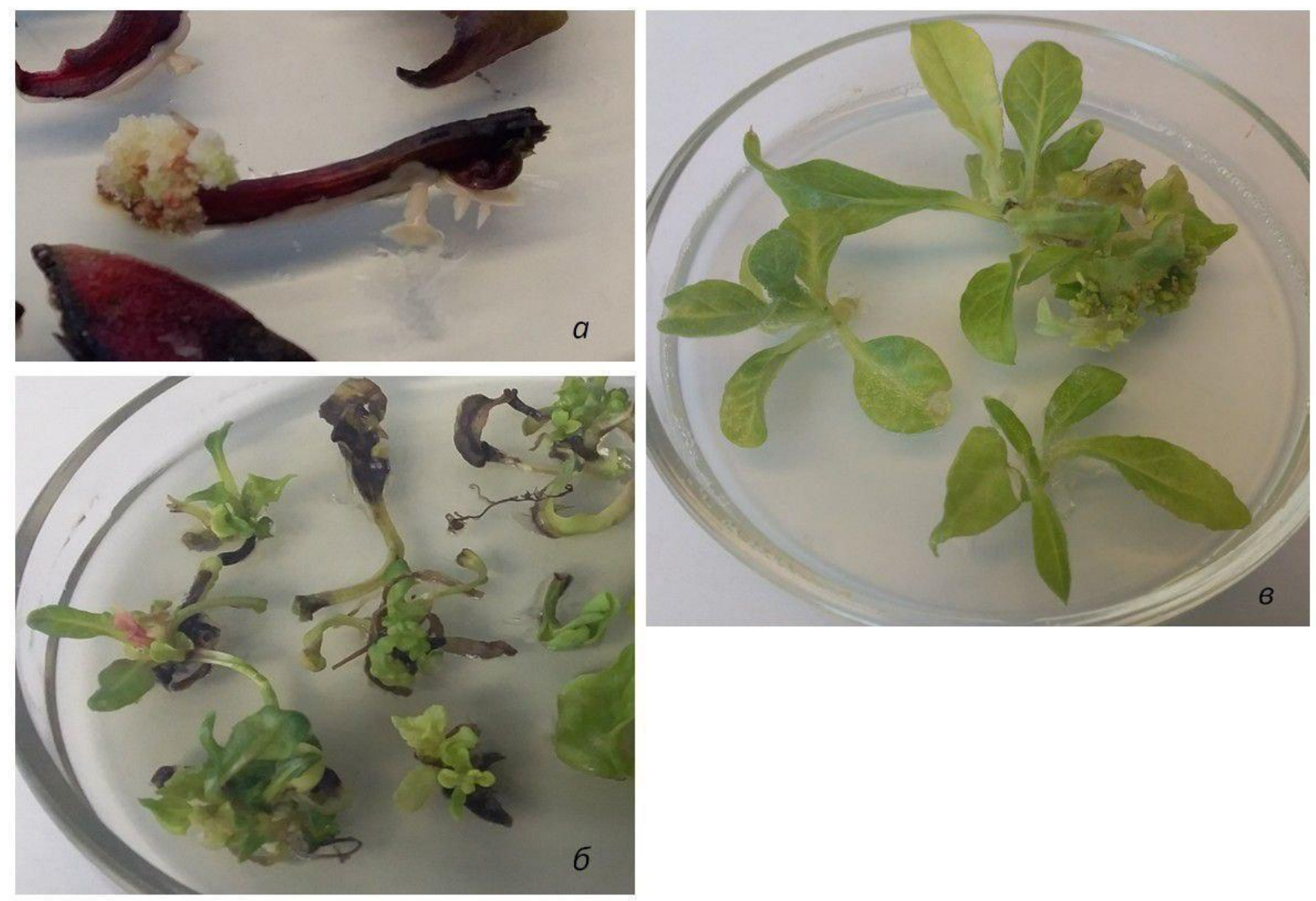

Рисунок 2. Ініціація калусогенезу на гіпокотильних експлантах мангольду (a), регенерація трансформованих рослин мангольду (б) та тютюну (в) на селективних середовищах 
Появу первинних калусних клонів рослин мангольду (рис. 2а) на живильному середовищі MS 3 додаванням регуляторів росту та антибіотиків у вказаних концентраціях, спостерігали через 2 тижні після A. tumefaciens-опосередкованої трансформації рослин. Не спостерігали ініціації калусогенезу для контрольних експлантів, які не піддавали генетичній трансформації, при культивуванні на живильному середовищі 3 додаванням 100 мг/л селективного антибіотику канаміцинсульфату. Перші регенеранти формувалися шляхом соматичного ембріогенезу через 2 - 3 місяці (рис. 2б).

Утворення перших регенерантів тютюну (рис. 2в) спостерігали через тиждень після трансформації. Отримані трансформанти характеризувалися стійкістю до антибіотику канаміцинсульфату.

Згодом було проведено ПЛР-аналіз на присутність в гена (рис. 3), що відповідає за синтез білка інтерферону альфа 2b (HuINFa-2b) та власного гену агробактерії (virDl). ПЛР-аналіз дозволив підтвердити присутність селективного nptII та цільового HuINFa-2b генів для 90$100 \%$ досліджуваних рослин, крім того, аналіз підтвердив відсутність бактеріального забруднення.

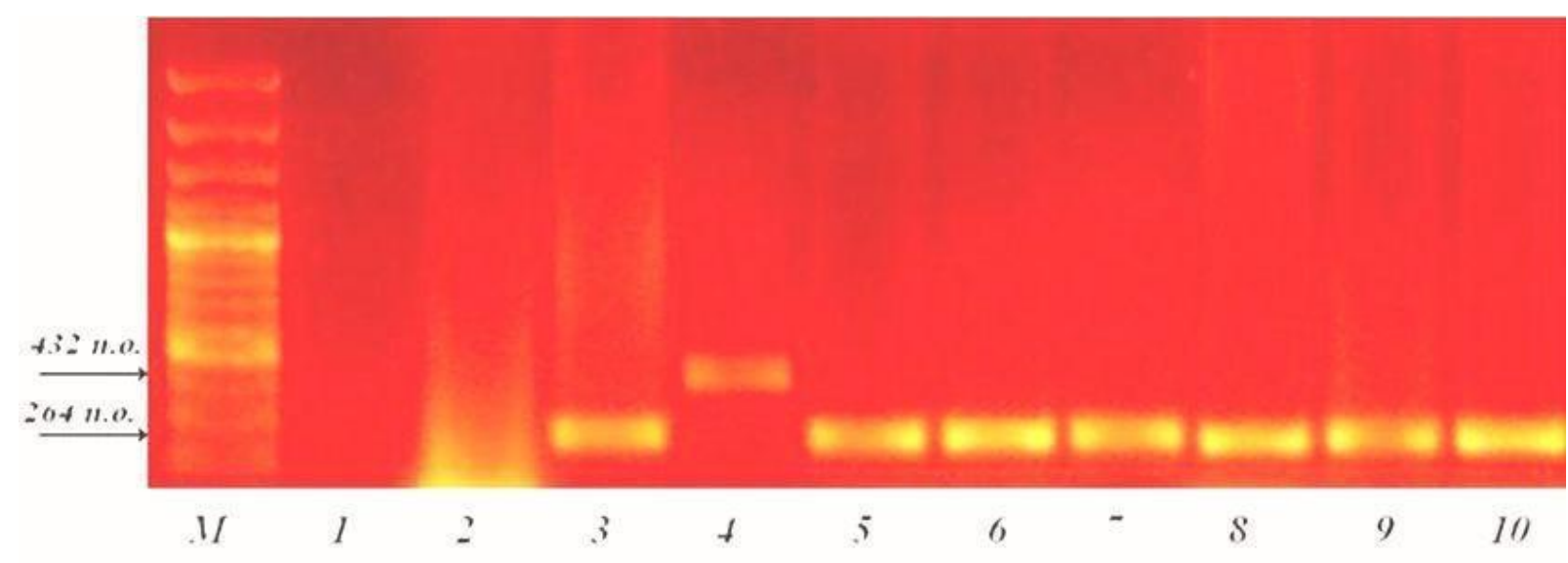

Рисунок 3. ПЛР-аналіз (дуплекс на присутність HuINFa-2b тa virD1 генів) трансформованих рослин тютюну Nicotiana tabacum L,

де M - ДНК маркер (1 Kb Plus DNA Ladder, Fermentas);1 - негативний контроль (проба без ДНК);2 - негативний контроль (ДНК нетрансформованої рослини); 3 - позитивний контроль (плазмідна ДНК рСВ124); 4 - позитивний контроль (ДНК A.tumefaciens GV3101);

5-10 - ДНК аналізованих рослин.

Можливість відтворення активних рекомбінантних інтерферонів в рослинах було показано в низці наукових досліджень. Найвищим рівнем накопичення інтерферону альфа характеризувалися трансгенні рослини топінамбуру виду Heliathus tuberosus L. (біологічна активність білка інтерферону альфа 2b становила від 2000 до $54500 \mathrm{MO}$ /г СВ) [9], моркви Daucus carota L. (антивірусна активність рослинних екстрактів від 16500 до $50700 \mathrm{MO} /$ С C) [10], Aloe vera L., (біологічна активність білка інтерферону альфа 2b становила до $2108 \mathrm{MO} /$ 
мг СРБ) [11], салату Lactuca sativa L. (біологічна активність білка інтерферону альфа 2b становила до $1140 \mathrm{MO} /$ лл рослинного екстракту) [12]. Проте, очевидно, що вміст та біологічна активність рекомбінантного інтерферону альфа залежить від виду рослин, що використовуються для експресії гену інтерферону. В подальшому ми плануємо визначення антивірусної та антипроліферативної активності екстрактів отриманих трансгенних рослин тютюну та мангольду.

\section{Література:}

1. Yano H. et al. Growth inhibitory effects of pegylated IFNa-2b on human liver cancer cells in vitro and in vivo, Liver International, 2006, №26, pp. 964-975.

2. Engler H. et al. Interferon alpha-2b gene delivery for bladder cancer demonstrates feasibility of repeated intravesical dosing with an adenovirus vector, Molecular Therapy, 2005, №11, pp. 210 211.

3. Jansen P.L.M. \& De Bruijne J. Controlled-release interferon alpha $2 b$, a new member of the interferon family for the treatment of chronic hepatitis C, Expert Opin. Investig. Drugs, 2012, № 21, pp.111 - 118, doi: 10.1517/13543784.2012.640671.

4. Zhou Q. et al. Interferon- $\alpha 2 b$ Treatment for COVID-19, Frontiers in Immunology, 2020, № 11, Article 1061.

5. Talpaz M. et al. Re-emergence of interferon-a in the treatment of chronic myeloid leukemia, Leukemia, 2013, №27, pp.803-812.

6. Hribernik A. et al. Effectiveness of electrochemotherapy after IFN- $\alpha$ adjuvant therapy of melanoma patients, Radiol Oncol, 2016, №50, pp. 21 - 27, doi:10.1515/raon-2015-0048.

7. El-Diwany R. et al. CMPK2 and BCL-G are associated with type 1 interferon-induced HIV restriction in humans, Science advances, 2018, №4, east 0843, doi: 10.1126/sciadv.aat0843.

8. Doyle J.J., Doyle J.L. Isolation of plant DNA from fresh tissue, Focus, 1990, №12, pp.13 - 15.

9. Maistrenko O.M. et al. Obtaining of the transgenic Helianthus tuberosus L. plants, callus and «hairy» root cultures able to express the recombinant human interferon alpha-2b gene, Цитология $и$ генетика, 2015, Vol. 49, №5, pp. 38 -44.

10. Luchakivskaya Yu. et al. High-level expression of human interferon alpha-2b in transgenic carrot (Daucus carota L.) plants, Plant Cell Reports, 2010, Vol. 30, №3, pp.407-415, doi: 10.1007/s00299-010-0942-5

12. Li Jing et al. Transient expression of an active human interferon-beta in lettuce. Horticulturae, 2007, Vol. 112, Issue 3, pp. 258 - 265. doi: 10.1016/j.scienta.2006.12.047. 